\title{
PEKERJAAN EARTHWORK DENGAN PENERAPAN METODE M-PERT DI AREA KAWASAN INDUSTRI
}

\author{
Sugeng Rahardjo ${ }^{a}$
}

\begin{abstract}
Earthwork Work with the Application of the PERT-Method in the Industrial Estate area. At the present time the need for industrial area in Indonesia is $2000 \mathrm{Ha} /$ year. The average delay in earthwork is $6.1 \%$ white the weight of earthwork work in a construction project reacted $13.48 \%$. In order to overcome the delay in implementation time, researchers used the M-PERT method can increase the accuracy of implementation time by 99\%, The processing The results of the statistical analysis obtained the influential factors in earthwork work on industrial areas based on the MPERT method which are: exavator selection, similarities in the network, combining activities, understanding PERT activities, manual calculation, recalculating PERT, increasing crashing time, identification of cut \& fill and effects duration of activity. Based on the validation results on the ripening work of the G1 plots in the industrial zone of Krakatau II Cilegon Banten, the application of M-PERT method, the result is 72, 55 days, which produced the error rate of $1.99 \%$.
\end{abstract}

Keywords: earthwork, PERT, M-PERT, industrial estate.

Abstrak: Pekerjaan Earthwork Dengan Penerapan Metode M-PERT di area Kawasan Industri. Saat ini kebutuhan lahan industri di Indonesia sebesar 2000 Ha/tahun. Rata-rata keterlambatan pekerjaan earthwork di dunia adalah sebesar 6,1\% sedangkan bobot pekerjaan earthwork dalam suatu proyek konstruksi mencapai 13,48\%. Untuk mengatasi keterlambatan waktu pelaksanaan, peneliti menggunakan metode Manual Program Evaluation and Review Technique (M-PERT). Metode M-PERT dapat meningkatkan akurasi waktu pelaksanaan sebesar 99\%. Pengolahan data statistik dilakukan dengan menggunakan SPSS, dari hasil dari analisa statistik diperoleh faktor-faktor yang berpengaruh dalam pekerjaan earthwork pada kawasan industri berbasis metode M-PERT yaitu: pemilihan exavator, kemiripan dalam jaringan, menggabungkan kegiatan, memahami kegiatan PERT, perhitungan secara manual, menghitung ulang PERT, meningkatkan waktu crashing, identifikasi cut and fill dan efek durasi aktivitas. Berdasarkan hasil validasi pada pekerjaan pematangan kavling G1 di kawasan industri Krakatau II Cilegon Banten, setelah menerapkan metode M-PERT, didapatkan bahwa total waktu yang dibutuhkan menjadi 72,55 hari dan dihasilkan tingkat kesalahan sebesar 1,99\%.

Kata Kunci:earthwork, PERT, M-PERT, kawasan industri

\section{PENDAHULUAN}

Berdasarkan data dari Kementerian Perindustrian RI memproyeksikan pada tahun 2014-2019 dibutuhkan lahan industri 10.000 hekatare yang terdiri dari 6.000 ha lahan untuk kawasan industri dan 4.000 ha lahan non kawasan industri di dalam kawasan peruntukkan industri [1], sehingga kebutuhan rata-rata sebesar $2.000 \mathrm{Ha}$ /tahun. Adanya hal tersebut maka harus segera dilakukan penyediaan lahan industri supaya dapat memenuhi kebutuhannya. Salah satu aktivitas dominan dalam penyediaan lahan industri adalah aktivitas earthwork yang meliputi pekerjaan survey lokasi, pengukuran, streeping, galian, urugan, perataan dan pemadatan serta test kepadatan tanah.

Keterlambatan pekerjaan earthwork di dunia, rata-rata adalah sebesar $6.1 \%$ [2], dengan adanya keterlambatan pekerjaan tersebut maka akan sangat menggangu dalam proses penyediaan lahan industri.

Saat ini ada beberapa metode penjadwalan proyek yang banyak di pergunakan dalam dunia konstruksi antara lain CPM, Line of Balance (LoB), PERT, Crashing, MPERT dan lain-lain. Masing-masing metode memiliki kelebihan, kekurangan dan karakteristik yang berbedabeda. Pada penelitian ini menggunakan metode

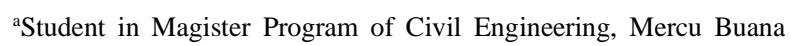
University (UMB), UMB Campus, Meruya Jakarta Indonesia a. Email: sugengr05@gmail.com penjadwalan M-PERT, yang merupakan metode terbaru kelanjutan dari metode PERT yang dapat memberikan akurasi perencanaan waktu pelaksanaan sebesar $99 \%$ atau dengan tingkat kesalahan sebesar $1 \%$ [3].

Dengan menggunakan metode M-PERT maka dalam penjadwalan proyek konstruksi lebih akurat, sehingga dapat menghindari terjadinya keterlambatan pekerjaan. Sedangkan dengan metode lain sampai saat ini belum ada yang dapat memberikan akurasi waktu penjadwalan proyek.

M-PERT adalah metode penjadwalan yang serupa dengan metode PERT, tapi M-PERT menggunakan kegiatan-di-node / activity of node (AON) yang berfokus pada hubungan mulai selesai, dan metode ini dihasilkan dari array proyek penjadwalan menampilkan total durasi pekerjaan konstruksi dengan penggabungan dua atau lebih proses aktivitas [4].

Besarnya bobot komponen pekerjaan earthwork / pekerjaan tanah dalam suatu proyek konstruksi adalah sebesar $13.48 \%$ [5]. Sehingga earthwork/pekerjaan tanah dalam proyek konstruksi manufaktur/industri mempunyai pengaruh yang menentukan dalam keberhasilan proyek tersebut. Oleh karena itu pelaksanaan pekerjaan earthwork/pekerjaan tanah harus efisien dalam aspek waktunya

Aktifitas manufaktur yang berlokasi di kawasan industri banyak mendapatkan keuntungan jika dibandingkan di luar kawasan industri (zona industri) antara lain tersedianya sarana dan prasarana serta infrastruktur yang memadai, terkendalinya limbah industri sesuai peraturan yang berlaku, terkendalinya masalah- 
masalah sosial, lingkungan, tenaga kerja, security dan lain-lain. Hal tersebut terjadi karena kawasan industri harus sesuai dengan Standar Teknis Kawasan Industri yang telah diterbitkan oleh Menteri Perindustrian [6]. [7]:

PERT memiliki enam langkah dasar sebagai berikut,

a. Mendefinisikan proyek dan menyiapkan struktur pecahan kerja.

b. Membangun hubungan antara kegiatan. Memutuskan kegiatan mana yang harus lebih dahulu dikerjakan dan mana yang harus mengikuti yang lain.

c. Menggambarkan jaringan yang menghubungkan keseluruhan kegiatan.

d. Menetapkan perkiraan waktu dan/atau biaya untuk tiap kegiatan.

e. Menghitung jalur waktu terpanjang melalui jaringan, ini yang disebut jalur kritis.

f. Menggunakan jaringan untuk membantu perencanaan, penjadwalan, dan pengendalian proyek.

Dalam jaringan PERT menetapkan tiga perkiraan waktu (three times estimates) untuk masing masing jaringan aktivitas [8]. Three times estimates meliputi:

a. Waktu optimis (optimistic time) $\left(\mathrm{t}_{\mathrm{o}}\right)$ : adalah waktu terpendek kejadian yang mungkin terjadi. Waktu yang dibutuhkan oleh sebuah kegiatan jika semua hal berlangsung sesuai rencana. Dalam memperkirakan nilai, Biasanya terdapat peluang kecil (katakanlah 1/100) bahwa wakto kegiatan akan $<\mathrm{t}_{\mathrm{o}}$.

b. Waktu pesimis (pesimistic time) $\left(\mathrm{t}_{\mathrm{p}}\right)$ : adalah waktu terpanjang kejadian yang dibutuhkan. Waktu yang dibutuhkan sebuah kegiatan dengan asumsi kondisi yang ada sangat tidak diharapkan. Dalam memperkirakan nilai ini, biasanya terdapat yang juga ke (juga, 1/100) bahwa waktu kegiatan akan $>t_{\mathrm{p}}$.

c. Waktu relistis (most probable times) $\left(\mathrm{t}_{\mathrm{m}}\right)$ : waktu yang paling tepat untuk menyelesaikan aktivitas dalam jaringan PERT, merupakan waktu yang paling sering terjadi jika suatu aktivitas diulang beberapa kali.

Pada Gambar 1 tentang diagram probabilitas PERT yang menggabungkan antara waktu dengan peluang terdapat $t_{o}, t_{p}$ dan $t_{m}$.

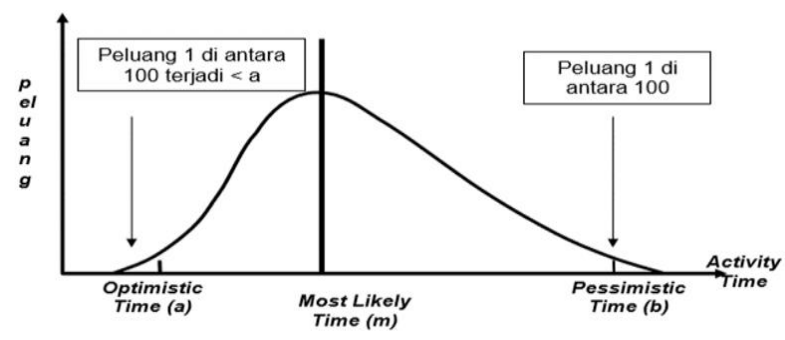

Gambar 1 Diagram Probabilitas PERT (Heizer dan Rander (2005))

$$
\begin{aligned}
& \mathrm{t}_{\mathrm{e}}=\left(\mathrm{t}_{\mathrm{o}}+4 \mathrm{~m}+\mathrm{t}_{\mathrm{p}}\right) / 6 \\
& \mathrm{~s}_{\mathrm{e}}=\left(\mathrm{t}_{\mathrm{p}}-\mathrm{t}_{\mathrm{o}}\right) / 6 \\
& \mathrm{v}_{\mathrm{e}}=\left\{\left(\mathrm{t}_{\mathrm{p}}-\mathrm{t}_{\mathrm{o}}\right) / 6\right\} \\
& \text { Keterangan: } \\
& \mathrm{t}_{\mathrm{e}}: \text { Expected time } \\
& \mathrm{t}_{\mathrm{p}}: \text { Pesimistis time } \\
& \mathrm{t}_{\mathrm{o}}: \text { Optimistis time }
\end{aligned}
$$

$\mathrm{s}_{\mathrm{e}}:$ Standard deviasi

$\mathrm{m}$ : Most likely

$\mathrm{v}_{\mathrm{e}}$ : Variansi

Dalam menentukan durasi suatu pekerjaan earthwork maka hal-hal yang perlu diketahui adalah volume pekerjaan dan produktivitas alat tersebut. Produktivitas alat berat bergantung pada kapasitas dan waktu siklus alat. Dasar untuk mencari produktivitas alat berat adalah:

Produktivitas $=$ Kapasitas alat $/ \mathrm{CM}$

Untuk memperoleh cycle time (CM) diperlukan sebagai berikut:

$$
\mathbf{C M}=\mathbf{T L}+\mathbf{T H}+\mathbf{T D}+\mathbf{T R}+\mathbf{T W}
$$

Dimana:

$$
\begin{aligned}
\mathrm{CM} & =\text { siklus waktu (cycle time) }(\text { detik) } \\
\mathrm{TL} & =\text { waktu pemutaran (detik) } \\
\mathrm{TH} & =\text { waktu pengangkutan (detik) } \\
\mathrm{TD} & =\text { waktu menumpahkan (detik) } \\
\mathrm{TR} & =\text { waktu kembali (detik) } \\
\mathrm{TW} & =\text { waktu menunggu (detik) }
\end{aligned}
$$

Sedangkan untuk menghitung jumlah alat-alat lainnya menggunakan rumusan sebagai berikut:

Jumlah Alat = produktivitas terbesar/produktivitas alat (6)

Setelah jumlah masing-masing alat diketahui maka selanjutnya perlu dihitung durasi pekerjaan alat-alat tersebut. Salah satunya cara dengan menentukan berapa Produktivitas total alat setelah dikalikan jumlahnya. Kemudian dengan menggunakan produktivitas jumlah alat maka durasi dapat dicari dengan menggunakan rumus sebagai berikut.

Durasi $=$ Vol pekerjaan $/$ produktivitas terkecil

Dalam pekerjaan earthwork ada beberapa metode yang bisa dilakukan, salah satu metode yang sering dipakai adalah metode balancing cut-fill. Metode ini sering dipakai karena kebanyakan area pekerjaan earthwork elevasi tanah existing yang bervariasi, yaitu terdapat beberapa area terdapat lembah dan beberapa area terdapat perbukitan. Metode ini adalah dengan melakukan penggalian atau pemotongan tanah pada area perbukitan yang jumlah volumenya sama dengan urugan pada area lembah yang ada pada area sekitarnya, sehingga pekerjaan bisa lebih cepat dan hemat biaya.

Dalam praktiknya, salah satu cara untuk mengurangi jumlah pekerjaan tanah adalah dengan mengatur garis grade sedekat mungkin dengan garis tanah sambil juga mempertimbangkan keseimbangan cut and fill [9].

Pada penelitian ini validasi proyek earthwork adalah menggunakan proyek pematangan kavling G1 seluas 5,628 Ha di area kawasan industri Krakatau II Cilegon Banten. Pada lahan tersebut direncanakan akan digunakan untuk lahan industri pembangunan pabrik dengan Gambar 2 berisi kontur existing tanah dan Gambar 3 berisi level rencana tanah. 


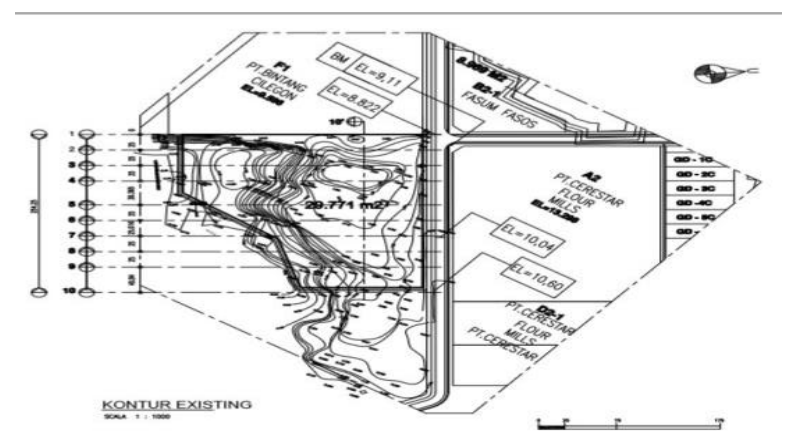

Gambar 2 Kontur Existing Tanah (PT Krakatau Industrial Estate Cilegon)

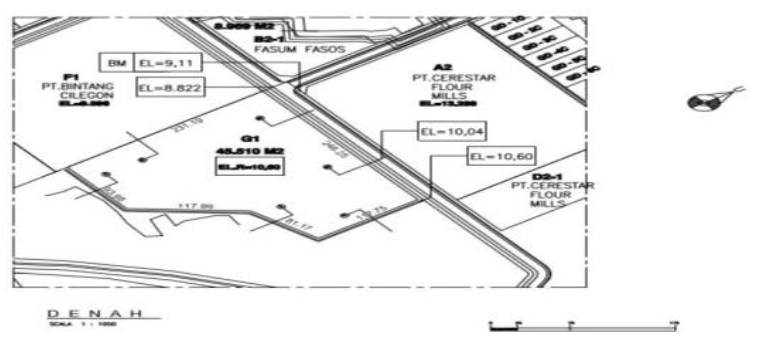

Gambar 3 Level Rencana Tanah (PT Krakatau Industrial Estate Cilegon)

\section{KEPENTINGAN RISET}

Penelitian mengenai penerapan metode penjadwalan proyek konstruksi telah banyak dilakukan penelitian baik dari dalam negeri maupun dari luar negeri. Penelitian mengenai penerapan metode penjadwalan M-PERT saat ini banyak menggunakan obyek pada proyek infrastruktur dan bangunan tingkat tinggi. Penelitian ini merupakan yang pertama kali dan dapat dijadikan reverensi bagi konsultan perencana proyek, menjadi masukkan dalam penentuan/ perencanaan penjadwalan pelaksanaan proyek konstruksi.

\section{METODOLOGI}

Untuk melakukan penelitian secara ilmiah, harus ada tahapan/urutan penelitian yang disesuaikan dengan kerangka penelitian yang telah disusun dalam bentuk diagram alir. Diagram alir disusun berdasarkan rumusan dan tujuan penelitian yang akan dicapai dengan mengacu pada kajian kelayakan proyek.

Pada penelitian ini di mulai dengan merumukan masalah dan judul penelitian yang di dukung dengan suatu kajian pustaka. Setelah itu ditentukan konsep dan hipotesa penelitian yang menjadi dasar untuk memilih metode penelitian yang tepat.

Proses penelitian seperti pada Gambar 4 secara garis besar ada 3 tahapan yaitu tahapan persiapan (preparation period), tahapan metodologi penelitian (reaserch metodology) dan tahapan penerapan penelitian (implementation reaserch). Pada tahapan persiapan berisi antara lain studi literature, reaserch gap, reaserch topik, state of the art, reaserch question sampai dengan hipotesis. Pada tahap metode penelitian berisi tentang indentifikasi variabel, pengumpulan data, pemodelan, sedangkan pada tahapan penerapan berisi tentang pengumpulan data, pengolahan data, uji hipotesa, kesimpulan dan saran.

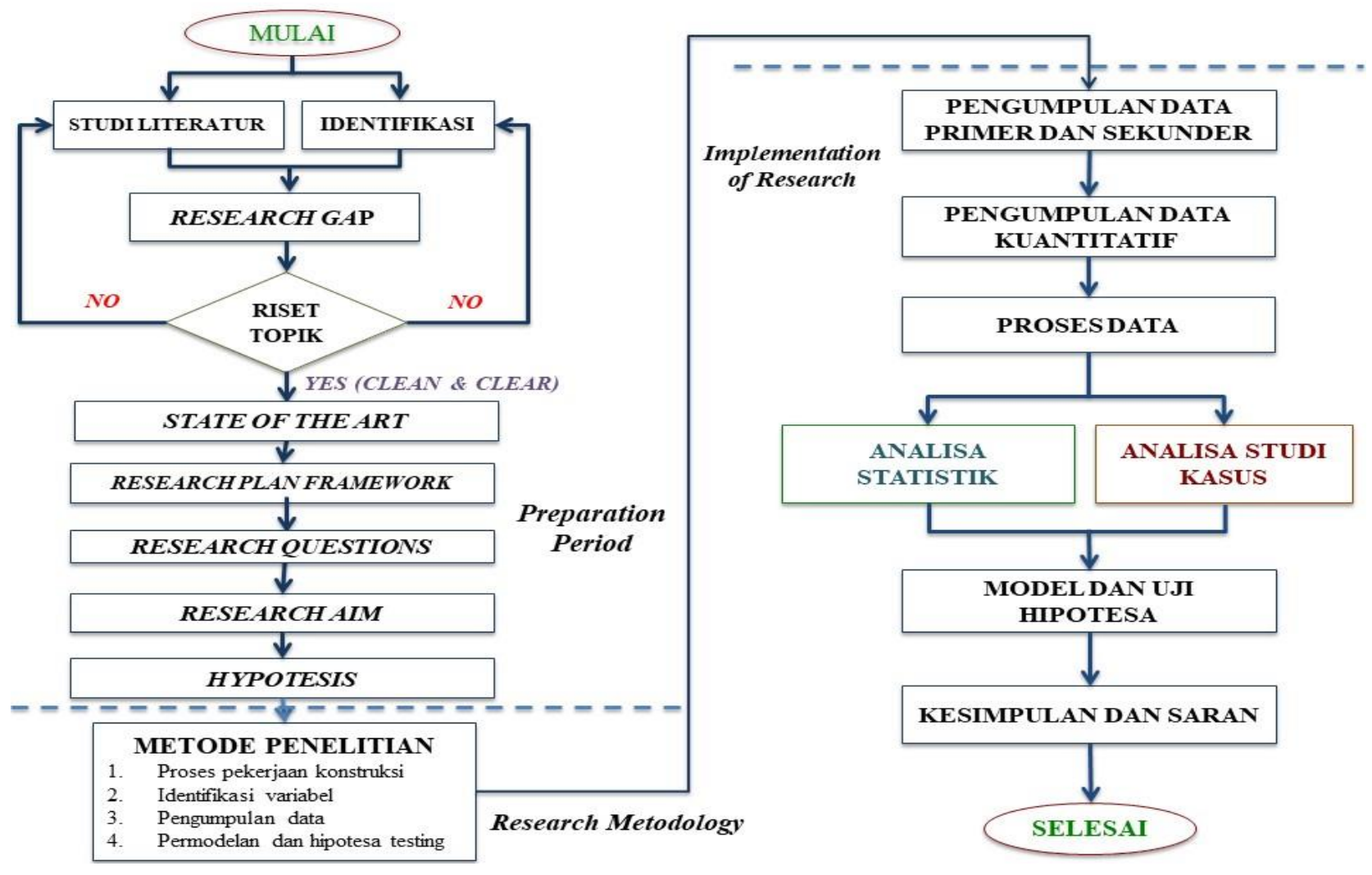

Gambar 4 Alur Penelitian 
Metode M-PERT adalah salah satu metode penjadwalan waktu pada proyek konstruksi yang telah berhasil diterapkan pada proyek jembatan oleh Ballesteros-Perez P pada tahun 2017. Pada penelitian ini metode penjadwalan M-PERT akan diterapkan pada proyek earthwork (pekerjaan tanah). Diharapakan dengan penerapan metode M-PERT pada proyek earthwork (pekerjaan tanah) maka waktu pelaksanaanya dapat lebih efisien dan akurasi perencanaan waktu pelaksanaan lebih meningkat.

Penerapan metode M-PERT pada proyek earthwork (pekerjaan tanah) di area kawasan industri akan dibuatkan dalam bentuk diagram flowchart penerapan metode MPERT sehingga memudahkan dalam memahaminya, melakukan monitoring serta evaluasi proyek konstruksi.

Memang metode yang diusulkan mudah untuk menerapkan dan mudah dipelajari sifat intuitif menyederhanakan asumsi. Hal ini membuat M-PERT alat yang menarik untuk mengajar dasar-dasar penjadwalan untuk konstruksi dan manageman proyek, terutama karena perhitungannya dapat dikembangkan secara

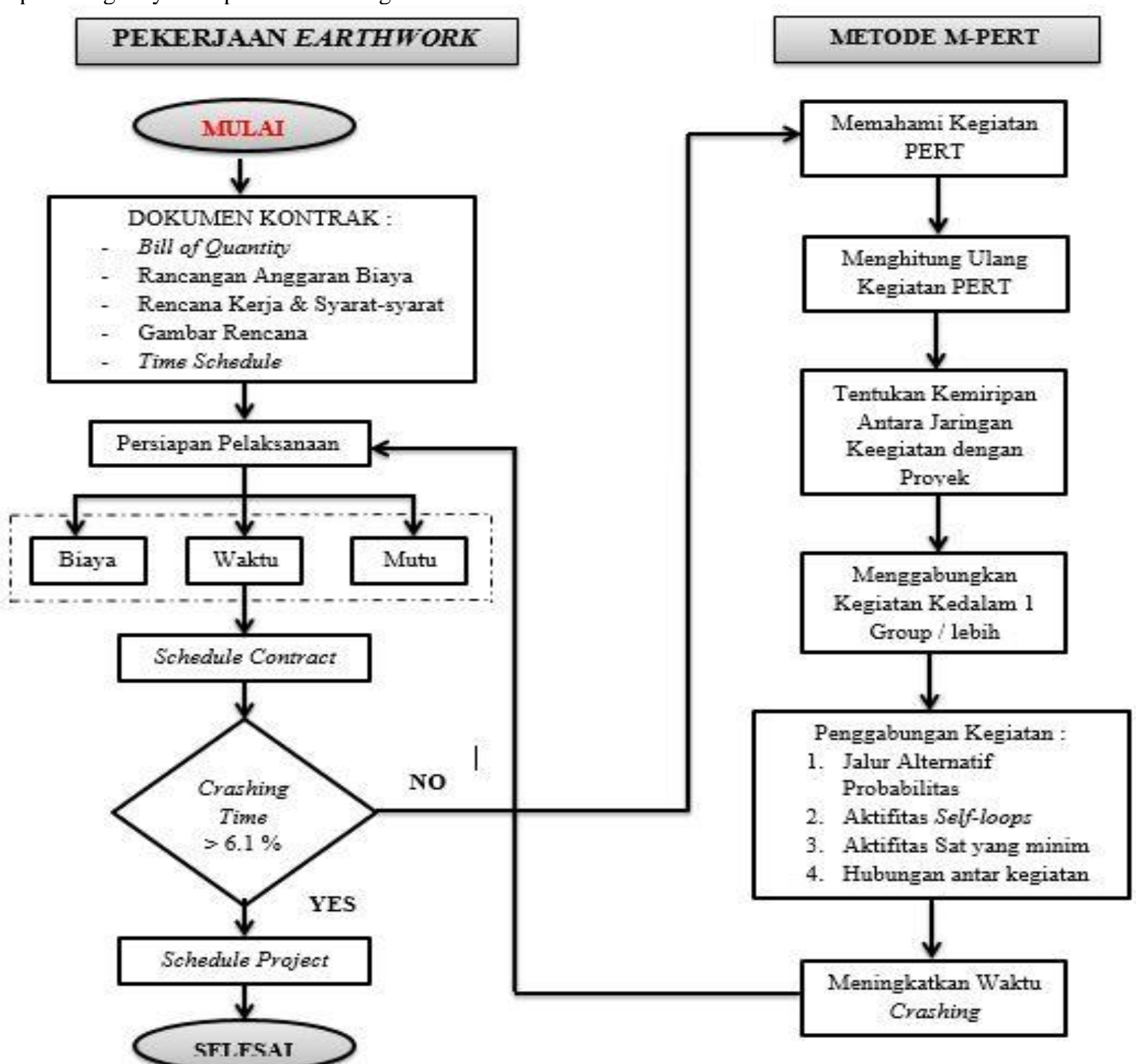

Gambar 5 Penerapan Metode M-PERT pada Pekerjaan Earthwork sederhana.[3].

Dengan adanya penerapan penggabungan secara manual M-PERT maka dapat membantu dalam pembuatan penjadwalan proyek secara maksimal dalam perencanaan waktu pelaksanaan suatu proyek konstruksi serta dapat mengetahui akurasi waktu pelaksanaan suatu proyek konstruksi. Metode M-PERT sangat membantu para Engineer dalam merencanaan waktu pelaksaan yang akurat sesuai dengan kondisi yang terjadi lokasi proyek.

Pada Gambar 5 detail penerapan metode M-PERT pada proyek earthwork (pekerjaan tanah) adalah seperti di bawah ini yang di buat menjadi 2 kolom, yaitu kolom pekerjaan earthwork, dimulai dari dokumen kontrak, persiapan waktu pelaksanaan, schedule Contract, Crashing time terakhir schedule project dan metode MPERT. Adapun integrasi penerapannya dimulai dari pekerjaan earthwork dilanjutakan penerapan metode MPERT manual atau dengan cara spreadsheet sangat 
Pengolahan data statistik pada penelitian ini dengan menggunakan software Microsoft Excel 2010 dengan metode Statistical package for the Social Sciencis (SPSS) Statistics 25, hasil output dari program SPSS tersebut akan dipergunakan untuk membuat kesimpulan dan saran.

Untuk memudahkan dalam proses pengolahan data statistika maka perlu di buatkan flowchat pengolahannya sesuai dengan Gambar 6. Adapun urutan prosesnya adalah dimulai dari input data, test data instrument, cek nilai cronbach's alpha, basic assumption test, classical assumption deviation test, descriptive analysis, correlation analysis, cek nilai $r$, linear regression analysis dan terakhir model testing. Untuk lebih detailnya dapat dilihat pada gambar flowchart di bawah ini.

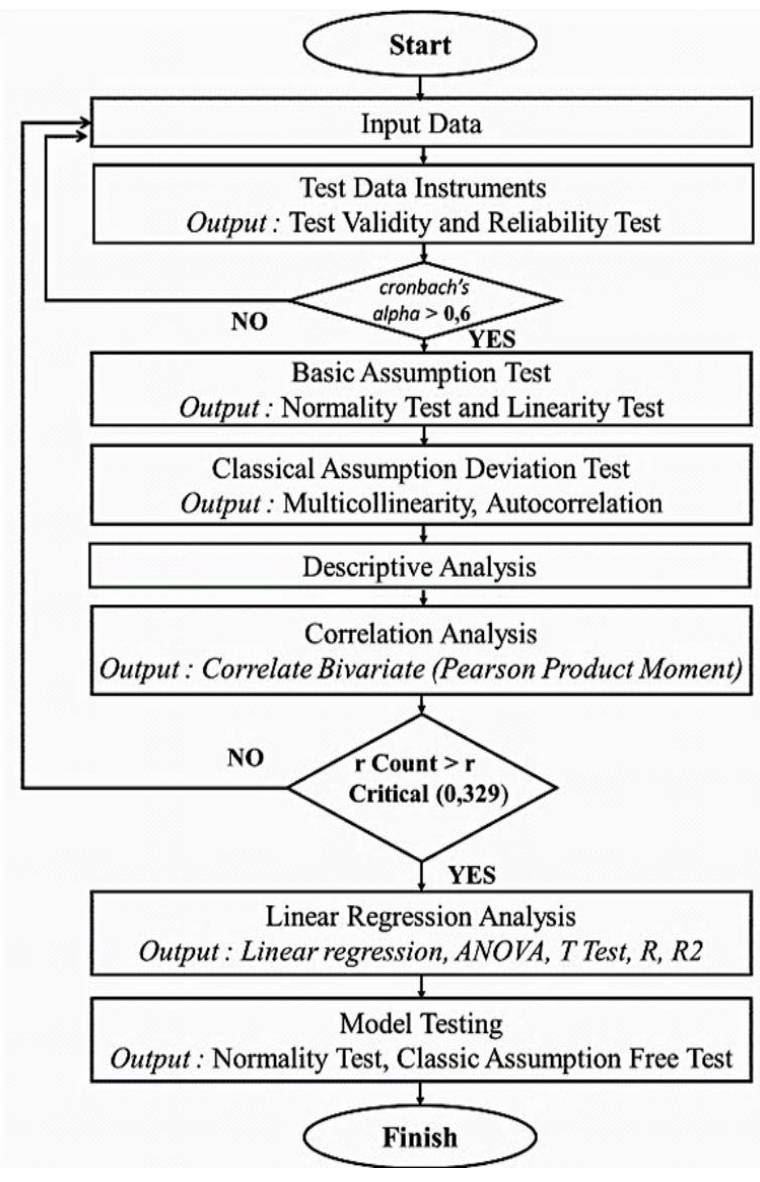

Gambar 6 Flowchart Pengolahan Data dengan SPSS

\section{ANALISIS DAN PEMBAHASAN}

Peneliti menetapkan 3 (tiga) variable utama untuk memperoleh pencapaian efisien waktu pelaksanaan proyek earthwork sebagai variable independen dan dependen. Variabel- variable utama tersebut adalah:

$\mathrm{Y}=$ Efisiensi Waktu

$\mathrm{X}_{1}=$ Obyek pada proyek earthwork

$\mathrm{X}_{2}=$ Aplikasi metode PERT \& M-PERT

Variabel independen \& dependen tersebut untuk dapat memenuhi persamaan regresi :

$$
\mathrm{Y}=\mathrm{a}+\mathrm{bX} \mathrm{X}_{1}+\mathrm{CX}_{2}
$$

Pada penelitian ini menggunakan 36 responden yang diambil pada kontraktor yang pernah mengerjakan proyek earthwork di area kawasan industri. Jabatan responden sesuai gambar 7 adalah terdiri dari project manager sebanyak 7 orang, site managers sebanyak 7 orang, engineering manager sebanyak 6 orang, supervesior sebanyak 13 orang dan surveyor sebanyak 3 orang.

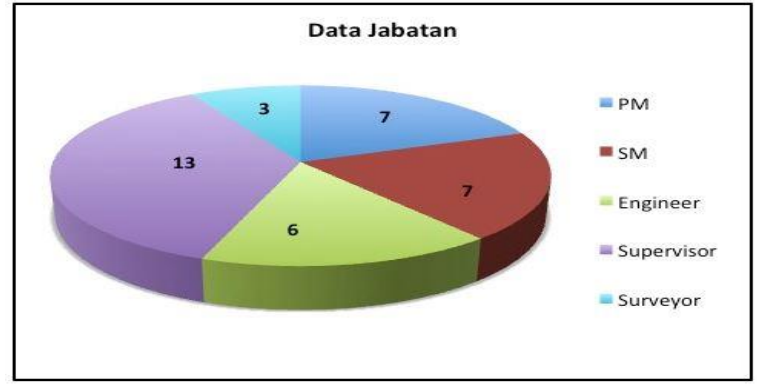

Gambar 7 Data Jabatan Responden

\section{Uji Reliabilitas}

Pada proses pengolahan data penelitian, maka atas datadata yang terkumpul dilakukan uji validitas dan uji reliabilitas terhadap masing-masing variabel untuk mengetahui validitas dan reliabilitasnya. Proses uji validitas dan reliabilitas tersebut dilakukan dengan menggunakan bantuan program SPSS, terhadap masing-masing variabel, yaitu variabel $\mathrm{X}_{1}$ (Obyek pada proyek earthwork) dan $\mathrm{X}_{2}$ (metode PERT dan M-PERT)

Skala nilai Alpha Cronbach itu dikelompokan kedalam lima kelas dengan rentang yang sama maka ukuran kemantapan alpha dapat di interpretasikan sebagai berikut [10]:

a. Nilai Alpha Cronbach 0,00 s.d. 0,20, berarti kurang reliabel

b. Nilai Alpha Cronbach 0,21 s.d. 0,40, berarti agak reliabel

c. Nilai Alpha Cronbach 0,41 s.d. 0,60, berarti cukup reliabel

d. Nilai Alpha Cronbach 0,61 s.d. 0,80, berarti reliabel

e. Nilai Alpha Cronbach 0,81 s.d. 0,100, berarti sangat reliabel

Reliabilitas suatu konstruksi variabel dinyatakan baik jika memiliki nilai Alpha Cronbach > 0,6. Kuesioner dinyatakan reliabel jika mempunyai nilai koefisien alpha yang lebih besar dari 0,6 [12].

a. Uji Reliabilitas Variabel $\mathrm{X}_{1}$ (Pekerjaan Earthwork)

Berdasarkan Tabel 1 dibawah ini maka mempunyai nilai cronbach's alpha sebesar 0,915 $(>0,60)$ sehingga variable tersebut telah dinyatakan reliabel. Arinya bahwa data-data tersebut adalah data yang konstan atau tetap, sehingga data data tersebut dapat dipakai untuk data penelitian tentang pekerjaan earthwork di kawasan industri dengan metode MPERT.

Tabel 1 Uji Reliabilitas Variabel $\mathrm{X}_{1}$ Reliability Statistics

\begin{tabular}{ccc}
\hline \multicolumn{3}{c}{ Reliability Statistics } \\
\hline \multicolumn{3}{c}{ Cronbach's Alpha } \\
Based on \\
Cronbach's & Standardized \\
Alpha & Items & Nof Items \\
.915 & .899 & 9 \\
\hline
\end{tabular}


b. Uji Reliabilitas Variabel $\mathrm{X}_{2}$ (Metode PERT \& M-PERT)

Berdasarkan Tabel 2 dibawah ini maka mempunyai nilai cronbach's alpha sebesar 0,974 (>0,60) sehingga variable tersebut telah dinyatakan reliabel. Arinya bahwa data-data tersebut adalah data yang konstan atau tetap, sehingga data data tersebut dapat dipakai untuk data penelitian tentang pekerjaan earthwork di kawasan industri dengan metode MPERT.

Tabel 2 Uji Reliabilitas Variabel $\mathrm{X}_{2}$

\begin{tabular}{ccc}
\hline \multicolumn{3}{c}{ Reliability Statistics } \\
\hline Cronbach's Alpha & Cronbach's Alpha Based on & Nof \\
.974 & Standardized Items & Items \\
& .972 & 19 \\
\hline
\end{tabular}

\section{Analisa Korelasi}

Untuk mengetahui hubungan antara setiap variabel independent dengan variabel dependent maka dilakukan analisis korelasi bivariate pearson sebagai berikut.

Pedoman untuk memberikan interpretasi koefisien korelasi sebagai berikut [10]:

$\begin{array}{llll}\text { 1. } & 0,00-0,20 & = & \text { sangat rendah } \\ \text { 2. } & 0,21-0,40 & = & \text { rendah } \\ \text { 3. } & 0,41-0,60 & = & \text { sedang } \\ \text { 4. } & 0,61-0,80 & = & \text { kuat } \\ \text { 5. } & 0,81-1,00 & = & \text { sangat kuat }\end{array}$

a. Korelasi antara variabel Y (efisiensi waktu) sebagai variabel dependen dengan variabel $\mathrm{X}_{1}$ (pekerjaan earthwork) sebagai variable independen, dapat dilihat pada Tabel 3.

Tabel 3 Korelasi Variabel Y-X

\begin{tabular}{cccc}
\hline \multicolumn{4}{c}{ Correlations } \\
\hline $\mathrm{Y}$ & $\mathrm{Y}$ & $\mathrm{X}_{1}$ \\
& Pearson & 1 & $.982^{* *}$ \\
& Correlation & & \\
Sig. $(2-$ tailed $)$ & & .000 \\
& $N$ & 36 & 36 \\
\hline $\mathrm{X}_{1}$ & Pearson & $.982^{* *}$ & 1 \\
& Correlation & & \\
& Sig. (2-tailed) & .000 & 36 \\
& $\mathrm{~N}$ & 36 &
\end{tabular}

Berdasarkan tabel output di atas, diperoleh nilai korelasi (r) antara pekerjaan earthwork dengan tingkat efisiensi waktu sebesar 0,982, dimana nilai $r$ tersebut dapat digolongkan sangat kuat. Hubungan kedua variabel tersebut adalah searah karena nilai $r$ adalah positif, sehingga dapat dikatakan bahwa pekerjaan earthwork dapat meningkatkan tingkat efisiensi waktu juga akan mengalami peningkatan.

b. Korelasi antara variabel Y (efisiensi waktu) sebagai variabel dependen dengan variabel $\mathrm{X}_{2}$ (metode PERT \& M-PERT) sebagai variable independen, dapat dilihat pada Tabel 4.
Tabel 4 Korelasi $\mathrm{Y}-\mathrm{X}_{2}$

\begin{tabular}{|c|c|c|c|}
\hline \multicolumn{4}{|c|}{ Correlations } \\
\hline & & $\mathrm{Y}$ & $\mathrm{X}_{2}$ \\
\hline \multirow[t]{4}{*}{$\mathrm{X}_{2}$} & Pearson & 1 & .8 \\
\hline & Correlation & & $73 * *$ \\
\hline & Sig. (2-tailed) & & .000 \\
\hline & $N$ & 36 & 36 \\
\hline \multirow[t]{4}{*}{$\mathrm{Y}$} & Pearson & $.873 *$ & 1 \\
\hline & Correlation & $*$ & \\
\hline & Sig. (2-tailed) & .000 & \\
\hline & $\mathrm{N}$ & 36 & 36 \\
\hline
\end{tabular}

Berdasarkan tabel output di atas, diperoleh nilai korelasi (r) antara pekerjaan earthwork dengan tingkat efisiensi waktu sebesar 0,873 , dimana nilai $\mathrm{r}$ tersebut dapat digolongkan sangat kuat. Hubungan kedua variabel tersebut adalah searah karena nilai $\mathrm{r}$ adalah positif, sehingga dapat dikatakan bahwa metode M-PERT dapat meningkatkan tingkat efisiensi waktu juga akan mengalami peningkatan.

\section{Analisa Regresi}

Tabel di bawah ini adalah hasil analisis regresi untuk seluruh variabel independen $\left(\mathrm{X}_{1}\right.$ dan $\left.\mathrm{X}_{2}\right)$ terhadap variabel dependen (Y), dimana $\mathrm{Y}$ adalah efisiensi waktu, sedangkan variabel $\mathrm{X}_{1}$ (proyek earthwork), $\mathrm{X}_{2}$ (Metode PERT, MPERT) yang dapat dilihat pada Tabel 5.

Tabel 5 Tabel Coefficients

Unstandardized Standardized

Coefficients Coefficients

1 \begin{tabular}{lccccc} 
Model & $\mathrm{B}$ & Error & Beta & $\mathrm{t}$ & Sig. \\
Constant & -2.899 & .538 & & -5.389 & .000 \\
\hline $\mathrm{X} 1$ & .552 & .038 & 1.083 & 14.601 & .000 \\
$\mathrm{X} 2$ & .056 & .050 & .241 & 1.130 & .267 \\
\hline
\end{tabular}

Berdasarkan tabel Coefficient di atas maka diperoleh persamaan regresi sebagai berikut:

$$
\begin{aligned}
& \mathrm{Y}=-2,899+0,552 \mathrm{X}_{1}+0,056 \mathrm{X}_{2} \\
& \text { Dimana: } \\
& \mathrm{Y} \quad=\text { Efisiensi Waktu } \\
& \mathrm{X}_{1} \quad=\text { Pekerjaan Earthwork } \\
& \mathrm{X}_{2}=\text { Metode PERT \& M-PERT }
\end{aligned}
$$

\section{Pembuatan Critical Path Method (CPM)}

Sebelum membuat penjadwalan program Evaluation and Riview Techique (PERT), peneliti harus membuat jalur kritis. Prosedur yang paling utama dari teknik penjadwalan proyek ini adalah CPM (Critikal Pert Method) yang diantara keduanya terdapat perbedaan penting. Kecenderungan pada saat ini adalah penggabungan kedua pendekatan tersebut yang biasa dikenal dengan sebutan PERT-type system. 
Tabel 6 Aktivitas Pekerjaan Pematangan Kavling G4

Aktivitas Uraian Unit Time (hari)

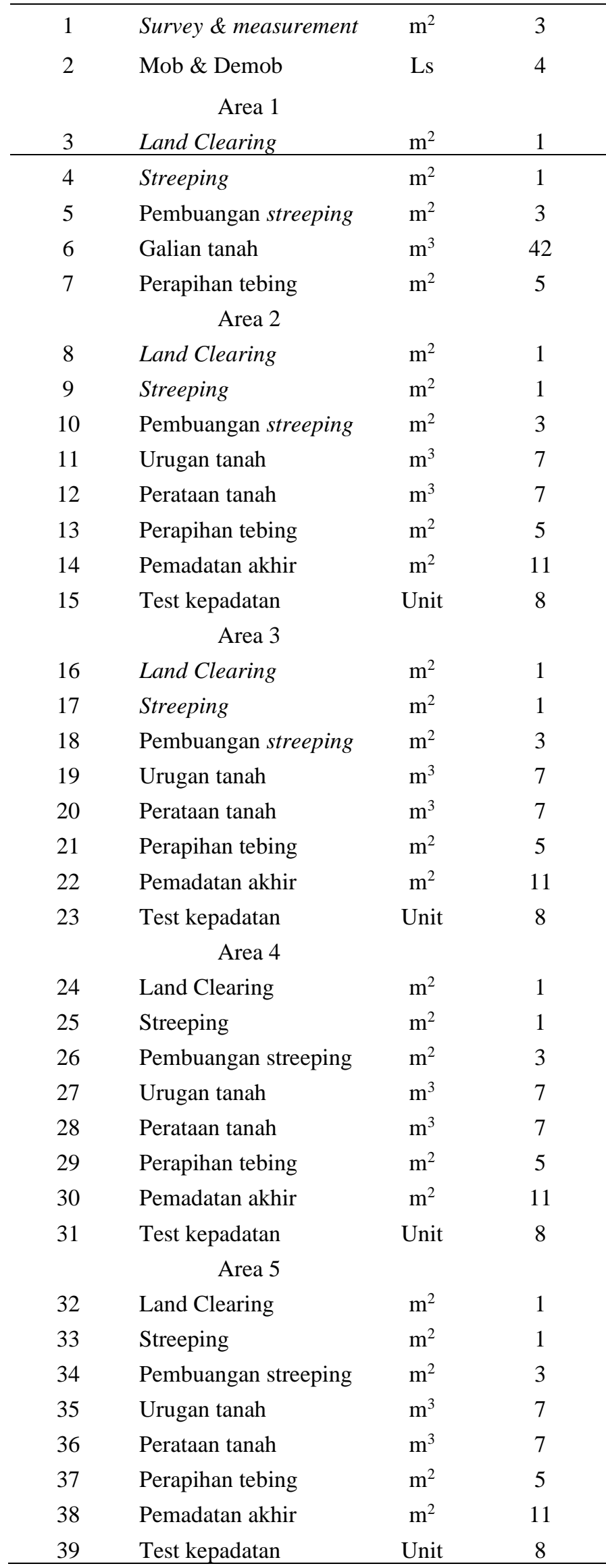

Berdasarkan data-data aktivitas pekerjaan pematangan kavling G4 di area Kawasan Industri Krakatau II Cilegon Banten sesuai dengan tabel di atas maka didapat jalur kritis pada diagram net work planning sesuai dengan Gambar 8

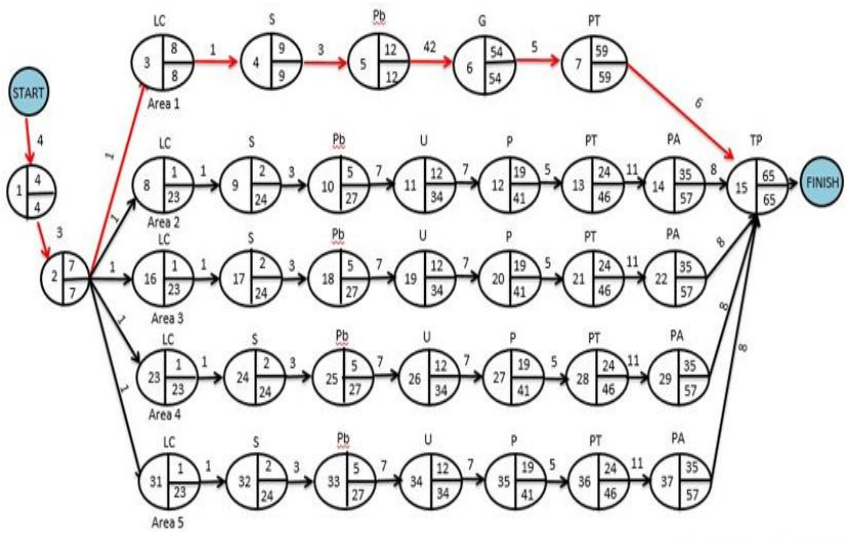

$\longrightarrow$ critical path

Gambar 8 Jalur kritis proyek pematangan kavling G4

\section{Tahapan Metode M-PERT}

\section{a. Tahap 1}

Terdapat 5 penggabungan yang terdiri dari aktivitas 3,4 , 5, 6 dan 7 dengan hasilnya adalah waktu 56,33 hari yang berasal dari penjumlahan durasi pada masing - masing aktivitas dan standar devisasi sebesar 11,12 sesuai Gambar 9.

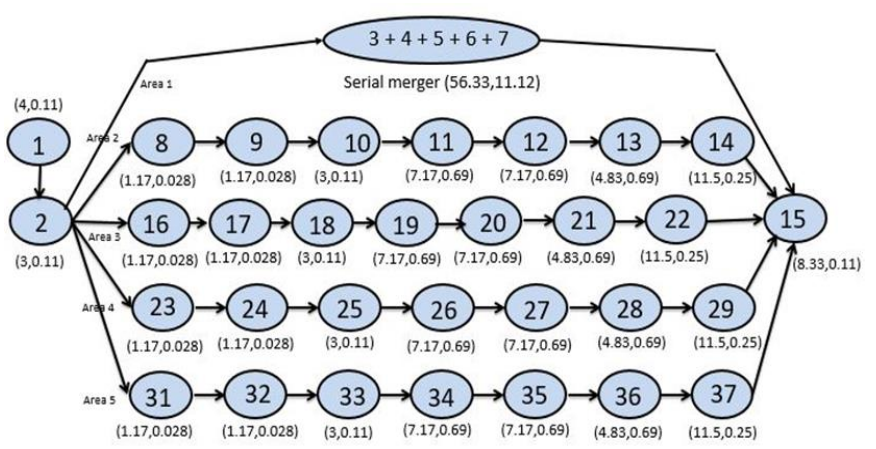

Gambar 9 Penggabungan Tahap 1, 5 Penggabungan

\section{b. Tahap 9}

Pada penggabungan seri tahap 2 terdapat 28 penggabungan yang terdiri dari aktivitas $8,9,10,11,12,13$, 14, 16 sampai dengan 37 dengan hasilnya adalah area 2 sampai dengan area 5 adalah waktu 36 hari dan standar devisasi sebesar 1,23 sesuai dengan Gambar 10.

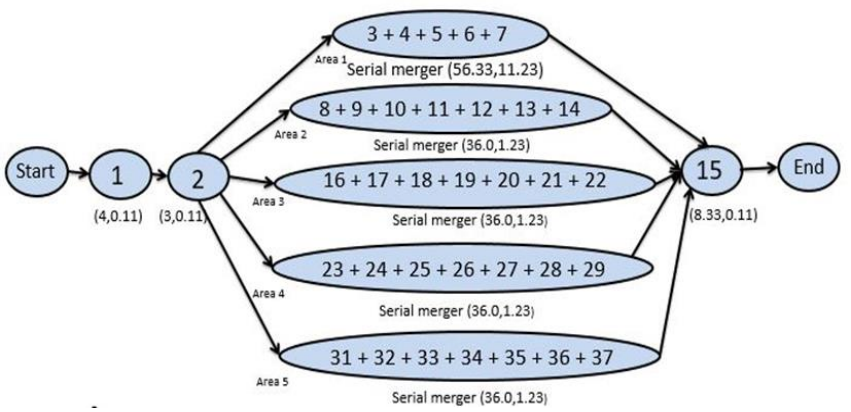

Gambar 10 Penggabungan Tahap 2, 28 Penggabungan 


\section{c. Tahap 3}

Pada penggabungan seri tahap 3 terdapat 4 penggabungan yang terdiri dari aktivitas $8,9,10,11,12,13,14,16$ sampai dengan 37 dengan hasilnya adalah area 2 sampai dengan area 5 adalah waktu 36 hari dan standar devisasi sebesar 1,23 sesuai dengan Gambar 11.

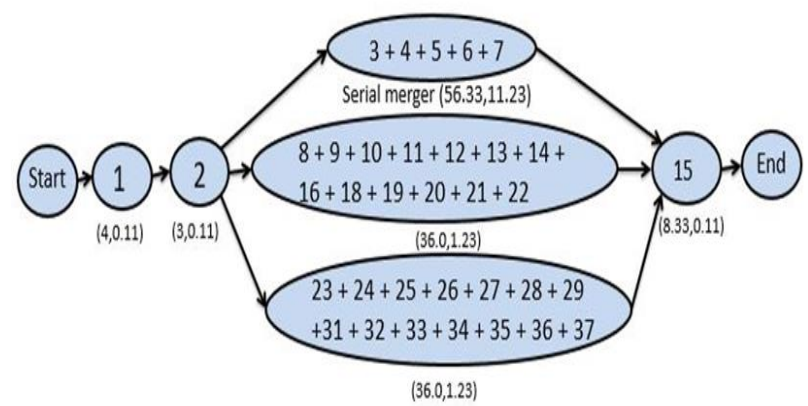

Gambar 11 Penggabungan Tahap 3, 4 Penggabungan

\section{d. Tahap 4}

Pada penggabungan seri tahap 4 terdapat 2 penggabungan yang terdiri dari aktivitas $8,9,10,11,12,13,14,16$ sampai dengan 37 dengan hasilnya adalah area 2 sampai dengan area 5 adalah waktu 36 hari dan standar devisasi sebesar 1,23 sesuai Gambar 12 .

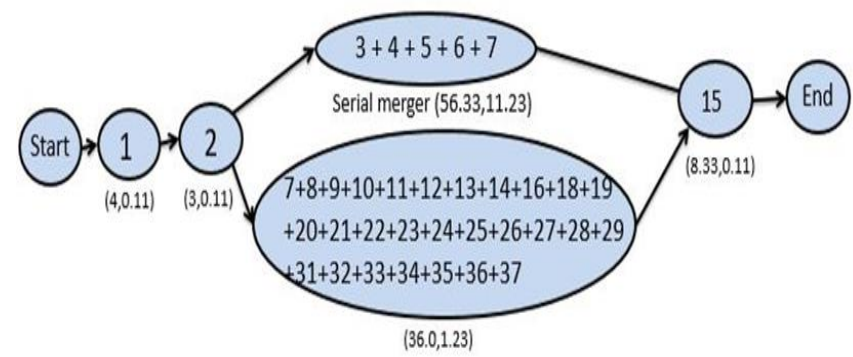

Gambar 12 Penggabungan Tahap 3, 4 Penggabungan

\section{e. Tahap 5}

Pada penggabungan seri tahap 5 terdapat 2 penggabungan yang terdiri dari aktivitas $3,4,5,6,7,8,9,10,11,12$, $13,14,16$ sampai dengan 37 dengan hasilnya adalah area 2 sampai dengan area 5 adalah waktu 57,22 hari dan standar devisasi sebesar 3,6 sesuai Gambar 13.

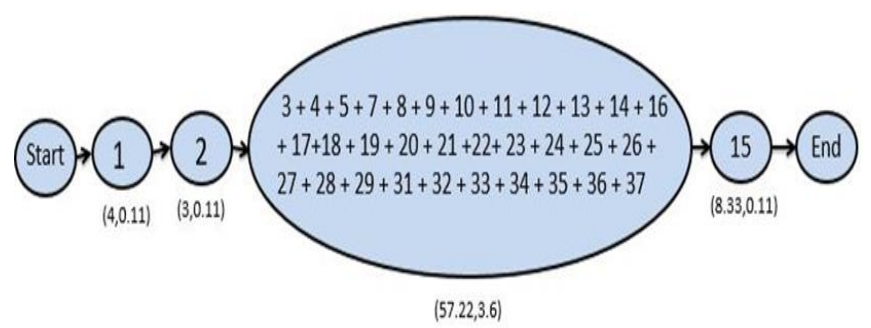

Gambar 13 Penggabungan Tahap 5, 4 Penggabungan

\section{f. Tahap 6}

Pada penggabungan seri tahap 5 terdapat 2 penggabungan yang terdiri dari aktivitas 1, 2, A, dan 15 dengan hasilnya adalah waktu 72,55 hari dan standar devisasi sebesar 3,6 sesuai dengan Gambar 14.

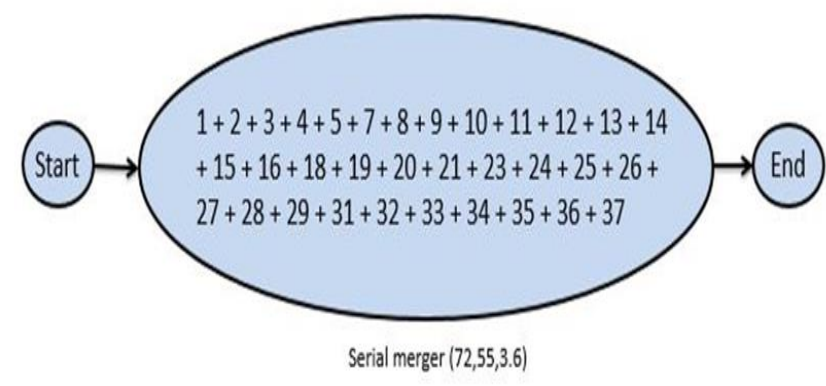

Gambar 14 Penggabungan Tahap 6, 4 Penggabungan

\section{KESIMPULAN}

1. Implementasi metode penjadwalan M-PERT pada proyek earthwork di kawasan industri sesuai dengan Gambar 5 tentang flowchart penerapan metode M-PERT.

2. Faktor-faktor yang berpengaruh dalam pelaksanaan pekerjaan earthwork adalah sebagai berikut: 1. Pemilihan exavator, 2. Kemiripan dalam jaringan, 3. Menggabungkan kegiatan, 4. Memahami kegiatan PERT, 5. Perhitungan secara manual, 6. Menghitung ulang PERT, 7. Meningkatkan waktu crashing, 8. Identifikasi cut and fill, 9. Efek durasi aktivitas

3. Waktu rencana pelaksanaan pekerjaan pematangan kavling G4 di kawasan industri Krakatau II adalah selama 77 hari. Berdasarkan perhitungan menggunakan data realisasi pekerjaan sebesar 74 hari maka dengan menggunakan metode M-PERT diperoleh sebesar 72,55 hari, sehingga akurasai sebesar 98,0\% atau terdapat tingkat kesalahannya sebesar $1,99 \%$

\section{DAFTAR PUSTAKA}

[1] Kementerian Perindustrian (2015) 'Rencana Induk Pembangunan Industri Nasional 2015 - 2035

[2] Rahman H. A et al, (2006), Delay Mitigation in the Malaysian Construction Industry, Journal of Construction Engineering and Management 2006.132:125-133, DOI: 10.1061/(ASCE)07339364(2006)132:2(125).

[3] Pablo Ballesteros - Perez, "M-Pert: Manual Project Duration Estimation Technique for Teaching Scheduling Basic" ASCE 2017. Journal of Construction Engineering and Management 2017. 143 (9):04017063, DOI: 10.1061/(ASCE)CO.19437862.0001358 .

[4] Husin A. E and Sulistyaningtyas B C (2018), Time performance improvement of hospital building structure construction project by M-PERT utilization, IJSRET ISSN 2278-0882.

[5] Zachawerus, J. (2017). "Komponen Biaya yang Mempengaruhi Estimasi Biaya Pelebaran Jalan Nasional di Maluku Utara”. Jurnal Infrastruktur, Vol. 3, No. 2

[6] Keputusan Menteri Negara Penggerak Dana Investasi/Ketua Badan Koordinasi Penanaman Modal Nomor: 15/SK/1993 Tentang Tata Cara Permohonan Modal Dalam Negeri dan Penanaman Modal Asing.". Menteri Negara Penggerak Dana Investasi/Ketua BKPM. 23 Oktober 1993. 
[7] Heizer, Jay dan Barry Render. (2014). Manajemen Operasi. Salemba Empat. Jakarta.

[8] Heizer, Jay dan Barry Render. (2005). Operation Management. Prentice Hall. New Jersey

[9] Goktepe, A. Burak, and A. Hilmi Lav. 2003. "Method for Balancing Cut-Fill and Minimizing the Amount of Earthwork in the Geometric Design of Highways." Journal of Transportation Engineering 129(5): 564-71.
[10] Sugiyono. (2007). Metode Penelitian. CV. Alfa Beta. Bandung

[11] Triton, P.B. (2005). Manajemen Sumber Daya Manusia. Tugu Publisher. Yogyakarta.

[12] Nugroho, Bhuono Agung. (2005). Strategi Jitu Memilih Metode Statistik Penelitian dengan SPSS. Andi. Yogyakart. 